\title{
Methods for assessing the efficiency of investment programs of energy enterprises in the agricultural sector
}

\author{
Andrey Mandrykin ${ }^{1, *}$ and Yulia Pakhomova ${ }^{1}$ \\ ${ }^{1}$ Voronezh State Technical University, 14, Moscovskiy prospect, 394026, Voronezh, Russia
}

\begin{abstract}
The role and importance of the energy industry in the economy of any country are extremely large. Energy ensures the life of modern man, the functioning and development of industry. Energy costs shape the economic environment in which industrial enterprises and populations exist. The article reviewed financial planning methods and presented a model of gross income and total output costs. Organizational and methodological regulations and practical recommendations on investment management in the agricultural sector, taking into account the peculiarities of economic activity at electric power industry enterprises, are justified and developed. The mechanism of implementation of investment policy in electric power enterprises is presented, which includes joint coordination of the state and enterprises in terms of attracting financial resources
\end{abstract}

\section{Introduction}

In a new environment characterized by increased competition and emerging risk factors, energy enterprises, as independent market actors, have been forced to seek new approaches to governance. The most important way to increase the efficiency of financial and economic activities of energy enterprises and strengthen their market positions is to apply modern methods of financial management, including the development and improvement of methods of financial planning.

The processes that form the price policy begin with a study of the market processes of the environment, that is, the external and internal combination of factors. The definition of innovative activities to be implemented includes the price strategy of energy enterprises. Known types of strategies include offensive ones that use scientific and technological advances that allow enterprises to take a leading position in the market. Their implementation involves high costs, so in a period of limited funds may require enterprises to choose other, less effective strategies (defensive, simulation, etc.) that require less investment.

The objects of financial planning in the enterprise are cash stocks and business activities, which are expressed in the following concepts:

- Performance indicators (product or service cost, gross turnover, revenue, raw material costs, wages, rent);

\footnotetext{
*Corresponding author: mandrykin@mail.ru
} 
- Indicators of financial resources and requests (volume of own funds or loans, current and planned expenses);

- Financial relations between departments of the company;

- Cash flows of the organization (receipts, expenses, investments);

- Expenditure on tax liabilities;

- Indicators of financial stability.

The fundamental objective of financial planning in business is to determine the optimal ways of development achievable by increasing competitiveness, profitability and stability of growth, which are realized through the reasonable use of money received from production, investment or other activities.

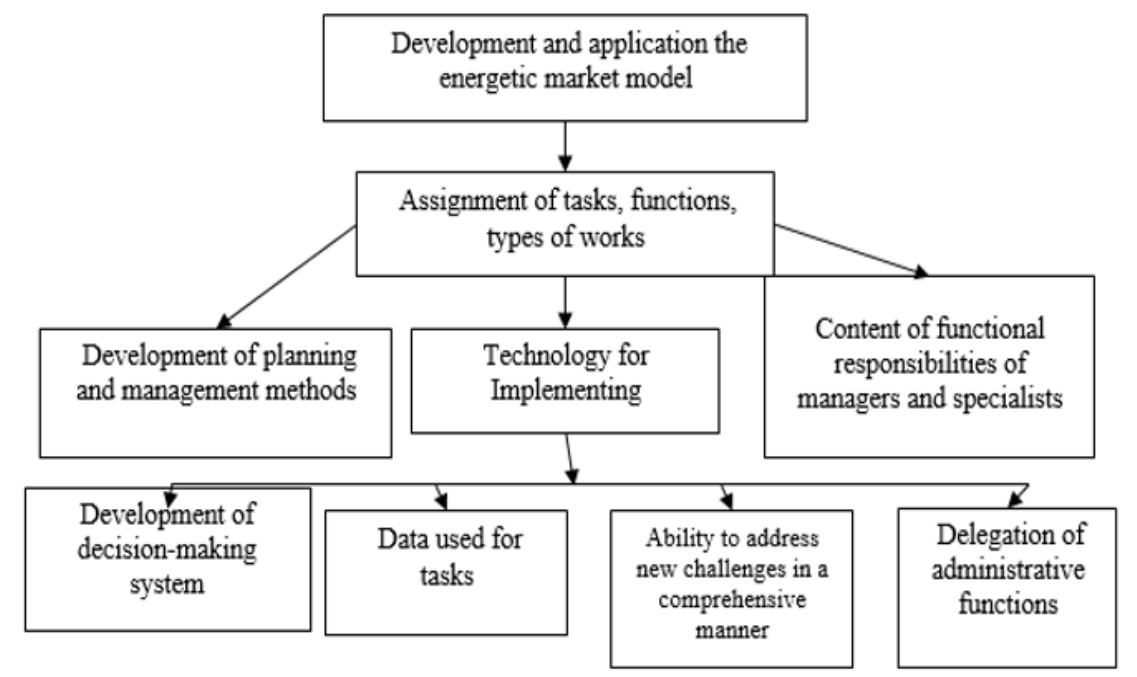

Fig. 1. Organizational model for release planning new products according to customer demand the main consumers.

Market conditions, competitive advantages are due to the need to choose price strategies (with high or low prices of analogues). Attracting investment, including for newly established, active and developing enterprises, is an important challenge. This requires a reasoned and justified design of projects (proposals) requiring investment.

This task can be accomplished by developing a business plan. The business plan is a special management tool used in the modern market economy, regardless of the scope and sphere of activity, as well as the forms of entrepreneurship. A business plan is a standard document for most market economies.

Each new enterprise or project inevitably faces certain difficulties threatening its existence. It is very important for the entrepreneur to be able to anticipate such difficulties and to develop strategies to overcome them in advance. You need to assess the level of risk and identify the problems that your business may face. The main risky points that business may face should be described simply and objectively.

Investment activities in electric power enterprises are fundamental to achieving high development indicators.

Due to the high wear and tear of the fixed assets of the electric power complex, the accident rate at the facilities increases, which subsequently leads to disproportionate damage compared to the cost of their modernization.

On the basis of a comprehensive study of the ongoing investment processes in the electric power industry, their peculiarities and specifics have been revealed. It was noted 
that the structure of the electric power industry has a significant specificity in different regions of the country depending on natural, climatic, economic and other factors.

The reform of the industry is an important factor affecting the projected size of profits and the current value of electricity companies. Changes, both in the nature and pace of reforms, often result in significant fluctuations in the industry 's share prices.

It should also be noted that the derivatives market in the new wholesale electricity market model is directly linked to the electricity market itself (the base asset market). Derivative financial instrument means a financial contract with standard or agreed terms and conditions whose value is derived from the underlying asset. The role of the basic asset in our case is performed by electric energy. In other words, the value of a financial instrument is determined by the price of the asset that is basic to that instrument.

As a result of the system analysis of the regulatory and legal framework, the conceptual basis for regulating the investment process in the electric power industry has been defined. It has been determined that the aim of the reform was to create a competitive electricity market and an environment in which electricity companies can attract the investments necessary to maintain and expand production capacity.

In connection with the existing scheme for the development of the electricity industry, it should be borne in mind that the main factor for attracting investments is the constant monitoring of the situation and the development of investment policies at the electricity enterprises themselves, taking into account the macroeconomic situation in the country and in the world.

\section{Materials and methods}

Russia 's electricity industry is the most important infrastructure industry designed to provide electricity and heat to the country 's economy and social sector with the necessary reliability and quality.

The state of the industry is currently characterized by an increasing shortage of generating capacity and insufficient development of electric networks. The capacity of power plants of the Russian electric power complex is 220.0 million $\mathrm{kW}$, the UES of Russia has 468 TPP with a total capacity of 138.7 million $\mathrm{kW}$. The installed capacity of hydroelectric power plants in 2007 was 46 million $\mathrm{kW}$. The installed capacity of 30 power units in 10 operating nuclear power plants is 23.5 million $\mathrm{kW}$. The length of electric networks of ECO of Russia with a voltage of more than $110 \mathrm{kV}$ is more than 442 thousand kilometers. The past decade has seen a significant deterioration in the industry 's economic performance.

Table 1. Structure of contribution to total growth rate of investments in fixed capital by sectors of economy, \%.

\begin{tabular}{|c|c|c|c|c|c|c|c|c|c|}
\hline & \multirow{2}{*}{} & \multirow{2}{*}{$\mathbf{2 0 1 8}$} & \multirow{2}{*}{$\mathbf{2 0 1 9}$} & \multirow{2}{*}{$\mathbf{2 0 2 0}$} & \multicolumn{2}{|c|}{$\mathbf{2 0 2 1}$} & \multicolumn{2}{|c|}{$\mathbf{2 0 2 2}$} & \multicolumn{2}{|c|}{$\mathbf{2 0 2 3}$} \\
\cline { 5 - 10 } & & & & $\mathbf{1}$ & $\mathbf{2}$ & $\mathbf{1}$ & $\mathbf{2}$ & $\mathbf{1}$ & $\mathbf{2}$ \\
\hline mining industry & 100 & 100 & 100 & 100 & 100 & 100 & 100 & 100 & 100 \\
\hline Metallurgical Group & 20.1 & 17.6 & 15.1 & 15.5 & 10.6 & 14.1 & 7.4 & 18.5 & 10.7 \\
\hline Metallurgical sector & 4.1 & 1.5 & 2.0 & 2.1 & 1.6 & 1.9 & 1.7 & 4.9 & 1.8 \\
\hline energy sector & 0.3 & 11.0 & 8.5 & 12.4 & 10.0 & 11.6 & 8.1 & 12.5 & 12.6 \\
\hline trade & 2.3 & 2.7 & 3.5 & 3.6 & 4.1 & 3.5 & 2.9 & 3.7 & 4.1 \\
\hline Communication & 4.1 & 5.1 & 4.1 & 4.1 & 5.4 & 3.5 & 4.3 & 3.8 & 5.8 \\
\hline
\end{tabular}


The main problem is insufficient investment in the power industry and reduced efficiency of investment, which has led to a sharp decline in the introduction of new capacity and threatening aging of fixed assets, increasing capacity shortages and unsatisfied consumer demand.

Table 1 shows that the contribution of the energy sector in 2018 was one of the lowest, and in 2019, due to the completion of the reform program, it increased significantly. According to the forecasts of the Ministry of economy of the Russian Federation, the achieved level of investment in the electric power industry will continue and according to various forecasts will amount to $10-12 \%$.

One of the major obstacles to maintaining high rates of economic development is the decline in investment activity in all sectors of the economy (figure 2). The most significant impact on the slowdown in investment demand is the continuing trend of declining business activity in the global financial markets.

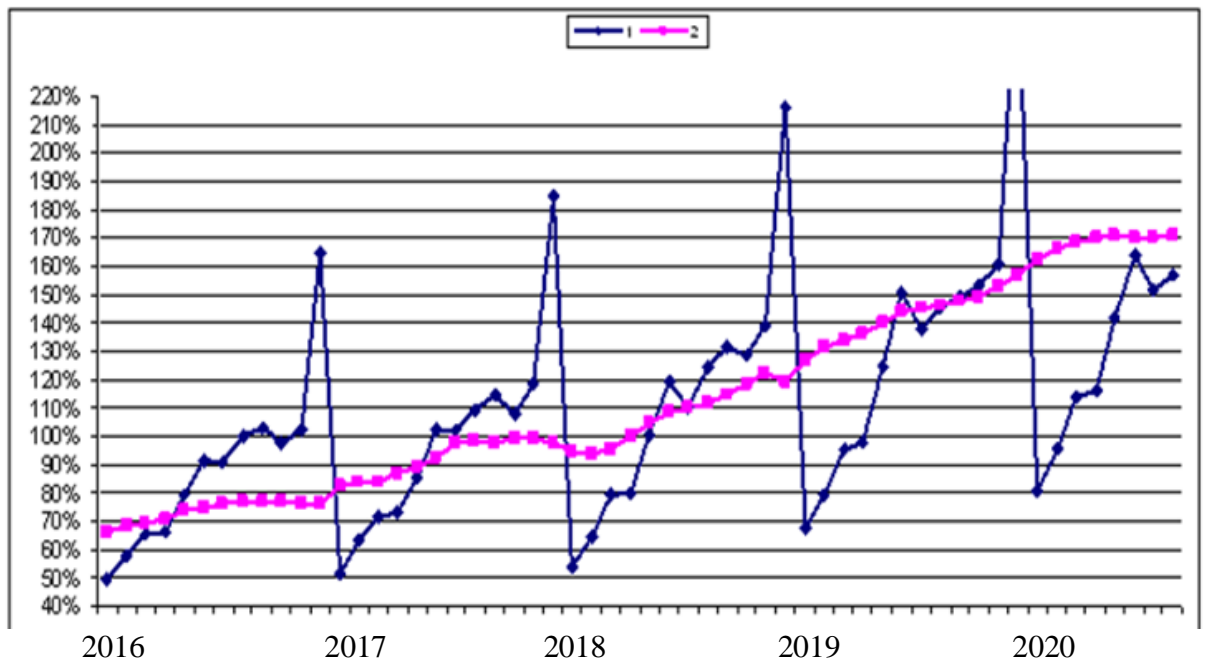

*1 Seasonally and calendar adjusted measure of investment

2 average investment indicator

Fig. 2. Investment activity in all sectors of the economy/

Plans to improve financial performance are being implemented by the company's planned services. The transition of energy enterprises to systems that operate on the basis of market (commercial) indicators increases the responsibility of the enterprise, which leads to the improvement of the quality of the financial plan.

\section{Results}

By means of financial planning of activities of socio-economic entities (enterprises), the system of selected goals is reproduced in the form of a specific financial indicator and data are analyzed, which allows to assess competitiveness of energy enterprises in conditions of strict market interaction [1].

As a result of the study of the theoretical basis of the investment process, it is determined that the goal of the investment policy of an electric power enterprise should be an effective investment of funds in new and reconstructed buildings and structures, equipment based on innovative production technologies by increasing the attracted funds. Financing of facilities at electric power companies should be at the expense of a competent investment policy, and not at the expense of increasing revenue (tariffs) for electricity. 
Table 2. Number of state owned shares of RAO UES of Russia.

\begin{tabular}{|c|c|c|}
\hline $\mathbf{3 0 . 0 6 . 2 0 1 9}$ & CBR & Share in the criminal code, $\%$ \\
\hline The property of the state & 22569848313 & 52,3457 \\
\hline $\begin{array}{c}\text { Federal Agency for Federal property } \\
\text { management }\end{array}$ & 22569834761 & 52,3457 \\
\hline Regional Agency & 13552 & 0,00003 \\
\hline The property of the state & 145523224 & 0,3375 \\
\hline $\begin{array}{c}\text { Federal Agency for Federal property } \\
\text { management }\end{array}$ & 145523224 & 0,3375 \\
\hline
\end{tabular}

The reorganization of RAO UES of Russia was the logical conclusion of the reform of the electric power industry and the creation of a new non-monopolized structure of the industry. Table 3 shows that the state was the main owner of RAO UES of Russia.

Table 3. The largest shareholders of JSC RAO "UES of Russia".

\begin{tabular}{|c|c|}
\hline Indicator & $\begin{array}{c}\text { The proportion of the share } \\
\text { capital, \% }\end{array}$ \\
\hline $\begin{array}{c}\text { The Russian Federation represented by the Federal Agency for } \\
\text { Federal property management }\end{array}$ & 52,6832 \\
\hline ING BANK (EURASIA) CJSC (nominee holder) & 15,6953 \\
\hline Joint-stock gas industry Bank (nominee holder) & 10,4900 \\
\hline " National Depository center "(nominee holder) & 8,9856 \\
\hline CJSC " Depository and clearing Company "(nominee holder) & 7,2715 \\
\hline
\end{tabular}

Thus, there is a change in the trend in the activities of generating companies - a period of large-scale investment replaces the period of effective operation of existing equipment.

In this regard, it is of interest to consider the IPR of the largest energy companies, such as PJSC RusHydro, Federal grid company.

According to the order of the Ministry of energy of the Russian Federation dated 29.12.2017 No. 34 "on approval of the investment program of PJSC RusHydro for 20182027 and changes to the investment program. The study of the main investment programs of electric power companies showed that companies consider several options as sources of financing (table 4).

Table 4. Sources of financing for the companies. Consolidated five-year investment program, for 2018-2027 (million rubles).

\begin{tabular}{|l|c|c|c|c|c|c|}
\hline \multicolumn{1}{|c|}{ Indicator } & $\begin{array}{c}\mathbf{2 0 1 8 -}- \\
\mathbf{2 0 1 9}\end{array}$ & $\begin{array}{c}\mathbf{2 0 2 0}- \\
\mathbf{2 0 2 1}\end{array}$ & $\begin{array}{c}\mathbf{2 0 2 2}- \\
\mathbf{2 0 2 3}\end{array}$ & $\begin{array}{c}\mathbf{2 0 2 4}- \\
\mathbf{2 0 2 5}\end{array}$ & $\begin{array}{c}\mathbf{2 0 2 6}- \\
\mathbf{2 0 2 7}\end{array}$ & Total \\
\hline investment projects & 814939 & 1034117 & 998486 & 814088 & 714238 & 4375868 \\
\hline Investments & 447346 & 456018 & 431202 & 372297 & 374468 & 2081330 \\
\hline Tariff sources & 137057 & 200546 & 234848 & 253305 & 281237 & 1106993 \\
\hline $\begin{array}{l}\text { Unused funds at the } \\
\text { beginning of the year }\end{array}$ & 3608 & 770 & 420 & 174 & 833 & 5804 \\
\hline
\end{tabular}




\begin{tabular}{|l|c|c|c|c|c|c|}
\hline $\begin{array}{l}\text { Issue of additional } \\
\text { shares }\end{array}$ & 181965 & 154965 & 66876 & 39954 & 17509 & 461269 \\
\hline $\begin{array}{l}\text { Payment for } \\
\text { technological } \\
\text { connection from } \\
\text { consumers }\end{array}$ & 1351 & 5511 & 6460 & 12526 & 14913 & 40761 \\
\hline $\begin{array}{l}\text { Other } \\
\text { Funds raised total }\end{array}$ & 123365 & 94226 & 122599 & 66337 & 59976 & 466504 \\
\hline Funds raised total & 292812 & 477765 & 479063 & 374653 & 279300 & 1903594 \\
\hline $\begin{array}{l}\text { Budget financing } \\
\text { Loans and borrowings }\end{array}$ & 125563 & 213834 & 245975 & 133610 & 89022 & 808004 \\
\hline $\begin{array}{l}\text { Advances on } \\
\text { technological } \\
\text { connection }\end{array}$ & 26356 & 36792 & 34845 & 25469 & 21620 & 145083 \\
\hline Other, including & 69357 & 144734 & 184157 & 198749 & 152298 & 749294 \\
\hline $\begin{array}{l}\text { The deficit at the } \\
\text { expense of budgetary }\end{array}$ & 7695 & 27479 & 50332 & 126277 & 88375 & 300157 \\
\hline Finance lease & 6973 & 2139 & 163 & 63 & - & 9338 \\
\hline VAT & 67808 & 98195 & 88058 & 67076 & 60469 & 381606 \\
\hline
\end{tabular}

Thus, the Consolidated investment program of companies for 2018-2027 (table 4) provides for the use of both own and borrowed funds.

Based on the analysis of the material and technical base, as well as ongoing investment processes in the field of electric power, the current problems of improving the investment policy at electric power enterprises are identified, which should include:

- insufficient investment capital, which leads to a decrease in the technological level of energy production and dangerous aging of fixed assets, a complete lack of investment attractiveness of the industry;

- deterioration of the efficiency of electricity and heat production;

- deterioration of financial stability indicators of most companies in the industry; the situation is aggravated by a huge accumulated debt;

- lack of the current system of tariff regulation based on the formula " cost plus»;

- imperfection of other forms of state regulation of the electric power industry;

- the existence of a variety of obligations existing in the industry of economic entities that are recognized by society, the state, and shareholders of energy companies, but, as a rule, are not explicitly stated;

- lack of conditions for fair competition in the industry, monopolization not only at the Federal, but also at the local level of all the main parts of the power industry;

- reduced reliability of fuel supply to power plants and consumers in many regions of the country; significant distortions in the structure of fuel resources consumed by the industry, primarily in the excessive share of gas;

- reduction of scientific and technical, power engineering and construction potentials;

- lack of an effective corporate governance system, etc. 
At the same time, overcoming negative factors is impossible without a deep analysis of the causes of the crisis and making decisions on reforming the electric power industry from the standpoint of national interests.

\section{Discussion}

An effective process of strategic partnership of electric power industry enterprises in order to attract investment is possible if the conditions of a single technological complex are met.

The economic mechanisms for ensuring the reliability of the industry include: differentiation of electricity tariffs by the level of reliability; the market for system services; insurance of damages caused by non-accounting conditions, etc.

The main goal of state regulation of the energy market is to improve the efficiency of resource allocation and increase public welfare by reducing losses due to the use of companies.

The conducted research allowed us to determine the priority directions of investment policy in the electric power industry:

1. Investments should be directed to the development of the existing and creation of a new network infrastructure of the market, ensuring its effective functioning.

2. It is necessary to build the most competitive and economical power generation facilities, the launch of which will reduce the level of prices for products.

3. Renovation, reconstruction and re-equipment of electric power complexes with the use of innovative, environmentally friendly technologies aimed at reducing cost, as well as the search for alternative types of electricity.

It is advisable to create a state investment Fund, the funds of which will be used for deficit-free development of the electric power industry, primarily for guarantee obligations to private investors in order to encourage financing of generating capacities of systemic significance and transmission networks.

As the corporate procedures for forming the target structure of OGK and TGC are implemented, the capitalization of generating companies, as well as the interest in these securities from portfolio investors, will grow. According to various forecasts, in order to ensure the development of electric power enterprises, the volume of investments should increase every year and reach $\$ 85$ billion by 2020. (figure 3 ).

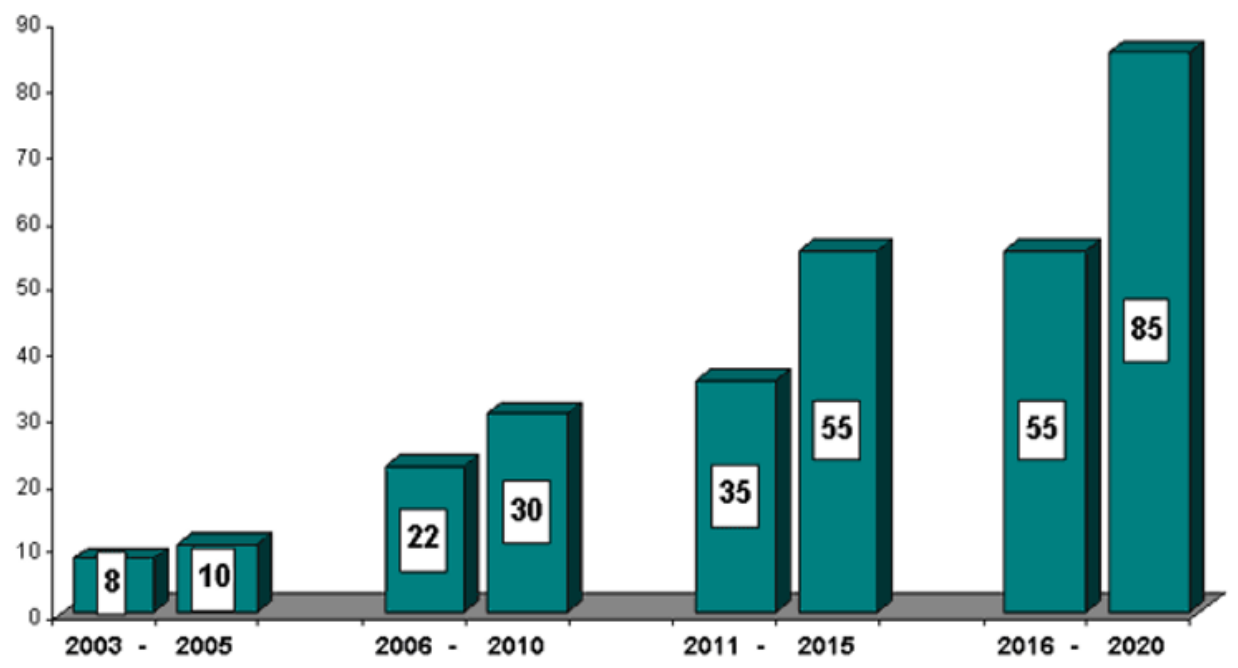

Fig. 3. Assessment of necessary investments in the electric power industry. 
Currently, Russia is completing the division of the vertically integrated structure of the electric power industry by type of activity into a set of economic entities of the energy market that represent the technological links of the electric power industry.

The analysis of economic relations between subjects of wholesale and retail electricity markets shows that regardless of their technological or territorial remoteness or disunity, differences in final goals, tasks and functions, the activities of all subjects are interconnected with the solution of a single task - providing consumers with electric energy, which is implemented in a single market space and using a single market technology. Their clear interaction in such a complex mechanism of market functioning is provided by both the legal framework and the system of multilateral and bilateral agreements that cover all subjects.

The importance of an effective investment policy in a transition economy increases significantly due to the fact that many enterprises in the material sphere of production have completely exhausted their financial and economic resources by irrational investment of funds.

It is the investment policy of the state that primarily affects the investment policy of enterprises. Stability and attractiveness of the investment policy of the state is one of the cornerstones of the organization of investment activity of any enterprise.

To ensure Russia's energy security, create a strategic reserve of capacity, further develop the energy system and create an international energy infrastructure in the future, it is necessary to implement major projects and create energy bridges connecting the OES of the Center, Siberia and the Far East.

An effective investment policy in the field of electric grid development should ensure the reliable and sustainable functioning of the Unified energy system of Russia, ensure the output of power plants, reliable supply to consumers, and create a competitive electricity and capacity market. According to the Ministry of economy of the Russian Federation, the growth rate of electricity production and distribution will increase during the implementation of the inertial and innovative development scenario (table 6).

Without stabilization of the state's investment policy, it is impossible to predict the improvement of investment activity at the level of individual economic entities, since an entrepreneur can only invest his own or, even more so, borrowed resources in conditions of sufficient predictability of monetary, tax, currency and budget policies, and stability of the legislative base.

The need for the most active participation of the state in the processes of regulation and management of the Russian electric power industry is due to the following. On the one hand, this industry is strategic, and its state directly affects national security and socioeconomic stability in the country, and, on the other hand, the state continues to be the largest owner in the electric power industry.

\section{Conclusion}

The final financial result of the company is represented by a system of such indicators as gross revenue (income), profit and profitability.

Revenue is the increase in economic resources derived from an influx of funds or a reduction in the costs and liabilities of a company. Revenues (gross revenues) include:

- income from primary activities - proceeds (income) from product sales, i.e. from realization of the electric power and heat;

- Income from other activities.

The main type of income of generating companies is revenue from sale of products, which includes: revenue from sale of electric energy and services: at regulated tariffs, revenue from sale of electricity at free prices on the market, revenue from sale of capacity, 
as well as revenue from sale of heat.

Revenue from sales of products (works, services) characterizes the completion of the cycle of production and sale of products, the return of funds advanced for production of the company in the form of cash and the beginning of a new cycle in the turnover of funds.

Expenses are recognized as any costs to the company provided they are incurred to carry out activities aimed at generating revenues, including:

- Costs of core activities, i.e. production and sales costs;

- Other costs (non-core costs)

Table 5. Forecast of average annual growth rates of electricity production and distribution under an inertial and innovative development scenario, $\%$.

\begin{tabular}{|c|c|c|c|}
\hline Resources $\quad$ Year & 2018-2020 & 2021-2023 & 2024-2027 \\
\hline Resources & 814939 & 1034117 & 998486 \\
\hline Production & $102.8-103.5$ & $102.9-104.2$ & $102.4-102.8$ \\
\hline Import & 63.8 & & \\
\hline \multicolumn{4}{|l|}{ Distribution } \\
\hline Export & $97.5-99$ & $111.5-114.0$ & 105.9-111.4 \\
\hline $\begin{array}{l}\text { Total consumption in the } \\
\text { economy }\end{array}$ & $102.7-104.6$ & $102.7-104.2$ & 102.3-103.7 \\
\hline Industry & $103.8-104.6$ & $103.0-104.2$ & $102.3-103.0$ \\
\hline Extraction of minerals & $107.5-108.3$ & $106.3-106.7$ & $104.8-106.0$ \\
\hline Chemical industry & 111.6-113.0 & 108.6-111.8 & 105.9-108.2 \\
\hline $\begin{array}{l}\text { Metallurgical production. } \\
\text { production of finished metal } \\
\text { products }\end{array}$ & $101.9-102.8$ & $100.8-102.4$ & $100.1-102.2$ \\
\hline $\begin{array}{l}\text { Production and distribution of } \\
\text { electricity. gas. steam. and } \\
\text { water }\end{array}$ & $100.7-101.2$ & $100.1-100.7$ & $100.1-100.2$ \\
\hline Transport and communications & 103.6-103.6 & $106.2-106.7$ & $105.9-107.7$ \\
\hline Consumption by the population & $100.7-100.7$ & $101.2-104.1$ & $100.9-103.5$ \\
\hline
\end{tabular}

The effectiveness of the corporate governance system of energy companies is one of the determining factors for the success of reforming the electric power industry, effective functioning and development of the industry. The following measures to improve corporate governance are appropriate:

- from the first stages of the reform, it is necessary to introduce separate accounting reports based on international accounting standards for the production, transmission and sale of electricity in all power companies, which is necessary to ensure financial transparency, more accurate accounting of costs by type of activity and preparation for subsequent restructuring;

- implementation of programs to improve the efficiency of energy companies, in particular, programs to save costs, inventory assets, pay off accounts receivable, reduce unjustified social obligations, etc.;

- increasing the role of the management bodies of joint-stock companies in discussion 
and decision-making; observing the rights of all shareholders of energy companies, in accordance with the share of their shares, in the preparation, discussion and decisionmaking; adopting the corporate governance code in each energy company; ensuring the effectiveness of judicial procedures for appealing insufficiently justified or unauthorized decisions or actions of the management of energy companies by all shareholders or their groups.

The developed functional algorithm for managing investment processes at electric power enterprises shows the order of system impact on the necessary components that ensure the functioning of the electric power complex, taking into account the interests of the state - the national economy of the country.

With the help of economic and mathematical models, the values of profit from the volume of revenues are expressed in the form of linear control.

$$
\mathrm{Z}=\mathrm{y}_{0}+\mathrm{y}_{1} \mathrm{R}
$$

where $\mathrm{Z}$ - profit amount, rub; $\mathrm{R}$ - revenue value, rub; y0; y1-Variables in the equation; $\mathrm{y} 1$ is the value of the regression coefficient, which shows the increase of profit with the increase of sales revenues by one ruble; y0 - profit, which is defined as the aggregate effect of factors, except for the indicator you are a handle from realization, rub.

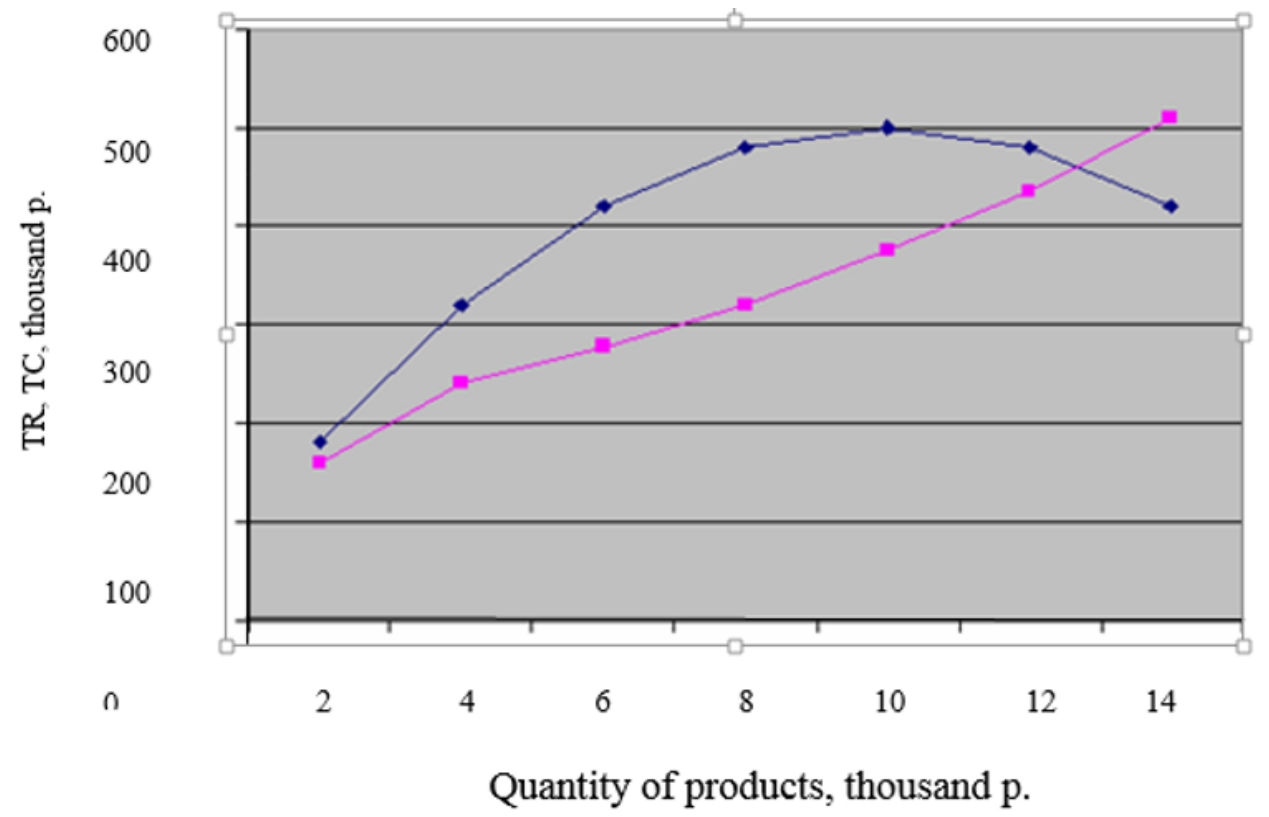

Fig. 4. The value of gross income and total output costs.

Thus, in solving dual problems of linear programming, sequential approximation methods are used, in which a close connection between pricing and marketing is achieved:

1. As a result of generalization of the theoretical foundations of investment policy research at electric power industry enterprises, scientific approaches to the formation of the investment climate in the electric power industry are systematized. It is shown that investment activity in newly formed energy enterprises is the basis for success.

2. Based on a comprehensive study of ongoing investment processes in the power industry, their features and specifics are identified. It is proved that the structure of the electric power industry has significant specifics in different regions of the country, depending on natural, climatic, economic and other factors. 
3. It is determined that the goal of the reform is to create a competitive electricity market and an environment in which electric power companies will be able to attract investment necessary to maintain and expand production capacity.

1. Based on the systematization of the theoretical base of investment processes, a scheme for the formation of the investment climate in the electric power industry is constructed.

2. As a result of the identified problems in the electric power industry, a mechanism for implementing investment policy at electric power enterprises has been developed.

Thus, ensuring the stable functioning and development of the country's economy and social sphere is possible with the stable development of the electric power industry.in this regard, a functional algorithm for managing investment processes at electric power enterprises in the interests of the national economy is proposed.

\section{References}

1. N.P. Lubshin, Analysis of Financial and Economic Activity of the Enterprise (UNITYAONF, Moscow, 2005)

2. G.A. Makhovikova, Planning at the enterprise: short course of lectures (Publishing House Jurayt, Moscow, 2010)

3. V.L. Inozemtsev, Split Civilization (Academia - Science, Moscow, 1999)

4. T.G. Gurnovich, M.I. Zakharova, Modern scientific research and development 8(8), 71-73 (2017)

5. N.I. Voropai, V.V. Trufanov, G.I. Sheveleva, Energy policy 2 (2004)

6. M.N. Krainina, Financial condition of the enterprise: methods of assessment (ICC DIS, Moscow, 2017)

7. Order of the Ministry of energy of Russia dated 09.09.2015 No. 627 "on approval of the scheme and program for the development of the Unified energy system of Russia for 2015-2021" (2017) http:// minenergo.gov.ru/node/1287

8. Order of the Ministry of energy of Russia dated 29.12.2017 No. 34 "on approval of the investment program of PJSC RusHydro for 2018-2027 and changes made to the investment program of PJSC RusHydro approved by the order of the Ministry of energy of Russia dated 30.12.2016 No. 1458" (2017) https://minenergo.gov. ru/node/4195 